\title{
Environmental impact of ongoing sources of metal contamination on
}

\section{remediated sediments}

\author{
Anna Sophia Knox, Michael H. Paller, Charles E. Milliken, Todd M. Redder, John R. Wolfe, \\ John Seaman
}

\section{GRAPHICAL ABSTRACT}

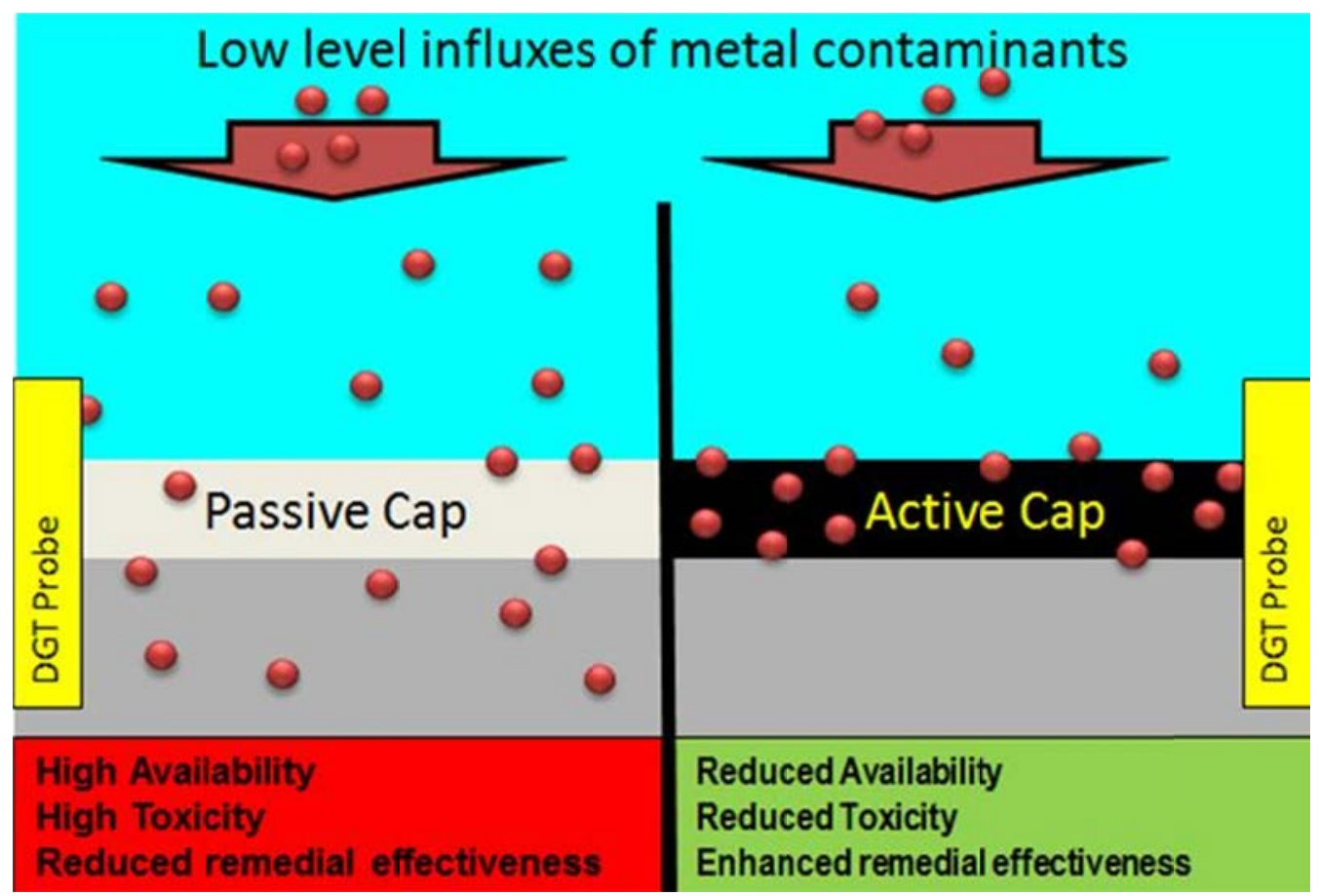

Conventional methods of remediating contaminated sediments may be inadequate for the

protection of benthic organisms when ongoing sources of contamination are present. However, sediment caps with chemically active sequestering agents have the ability to reduce the bioavailable pool of metals in ongoing sources of contamination (red dots), reduce toxicity to aquatic organisms, and enhance remedial effectiveness. 


\section{Environmental impact of ongoing sources of metal contamination on} remediated sediments

3

4 5

6

7

9 819-8406; FAX: 803 725-7673

10

11

12

13

14 E-mail: tredder@limno.com

15

16

17

18

19

20

21

22

23

E-mail: anna.knox@srn.doe.gov

E-mail: tredder@1imno.com

E-mail:jwolfe@limno.com United States.

E-mail: seaman@srel.uga.edu

* Corresponding author 1

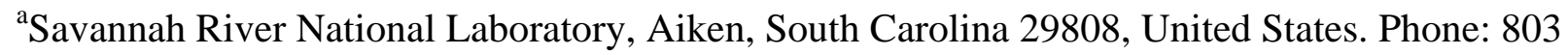

michael.paller@srnl.doe.gov

charles.milliken@srnl.doe.gov

${ }^{\mathrm{b}}$ LimnoTech, Ann Arbor, Minnesota 48108, United States.

c Savannah River Ecology Laboratory, University of Georgia, Aiken, South Carolina 29802, 


\section{ABSTRACT}

2 A challenge to all remedial approaches for contaminated sediments is the continued influx of

3 contaminants from uncontrolled sources following remediation. We investigated the effects of

4 ongoing contamination in mesocosms employing sediments remediated by different types of

5 active and passive caps and in-situ treatment. Our hypothesis was that the sequestering agents

6 used in active caps and in situ treatment will bind elements (arsenic, chromium, cadmium,

7 cobalt, copper, nickel, lead, selenium, and zinc) from ongoing sources thereby reducing their

8 bioavailability and protecting underlying remediated sediments from recontamination. Most

9 element concentrations in surface water remained significantly lower in mesocosms with apatite

10 and mixed amendment caps than in mesocosms with passive caps (sand), uncapped sediment,

11 and spike solution throughout the 2520 hour experiment. Element concentrations were

12 significantly higher in Lumbriculus variegatus from untreated sediment than in Lumbriculus

13 from most active caps. Pearson correlations between element concentrations in Lumbriculus and

14 metal concentrations in the top $2.5 \mathrm{~cm}$ of sediment or cap measured by diffusive gradient in thin

15 films (DGT) sediment probes were generally strong (as high as 0.98$)$ and significant $(\mathrm{p}<0.05)$ for

16 almost all tested elements. Metal concentrations in both Lumbriculus and sediment/cap were

17 lowest in apatite, mixed amendment, and activated carbon treatments. These findings show that

18 some active caps can protect remediated sediments by reducing the bioavailable pool of

19 metals/metalloids in ongoing sources of contamination.

\section{KEYWORDS}

22 Metals; passive caps; active caps; remediated sediment; bioavailability; re-contamination 


\section{Environmental impact of ongoing sources of metal contamination on}

2 remediated sediments

3 Anna Sophia Knox, Michael H. $\underline{\text { Paller, }}$ Charles E. Milliken, Todd M. Redder, John R. Wolfe,

4 John $\underline{\text { Seaman }}$

5

1. Introduction

7

8 Rapid industrialization and urbanization has led to the contamination of sediments with heavy

9 metals and organic contaminants and created a pervasive problem worldwide. Major sources of contamination include agricultural and urban lands, industrial activities, spills, and accidents.

11 Arsenic (As), cadmium (Cd), cobalt (Co), copper (Cu), mercury (Hg), nickel (Ni), lead (Pb), and

12 zinc (Zn) are often found in harbor sediments and other areas affected by anthropogenic

13 activities. Sediments containing these contaminants act as secondary sources of contamination,

14 posing significant direct and indirect environmental risks through bioaccumulation in aquatic

15 organisms and incorporation into aquatic food webs that may lead to human exposure (NRC,

16 2003). Episodic physical redistribution of contaminated sediments within dynamic waterways

17 over time can disperse such risks, potentially affecting biological and water quality conditions far

18 from the original sediment source over long periods (Admiralet al., 2000; Beachler et al., 2003).

The remediation of contaminated sediment requires lowering chemical risks to ecological receptors and human health via the removal, elimination, or reduction of contaminant release and

21 uptake (U.S. EPA, 2005). The most commonly used methods to remediate metal contaminated

22 sediments are environmental dredging, followed by monitored natural recovery, passive and

23 active capping, and in situ remediation techniques. Environmental dredging involves the removal 
1 of contaminated sediment from freshwater or marine water bodies to reduce risks to human

2 health and the environment. Removal is particularly effective for source control (mass removal

3 of hot spots) but potentially less effective for overall risk reduction because of resuspension and

4 residual contamination (ITRC, 2014).

Capping and related in situ remediation techniques are usually less energy-intensive, less

6 expensive, and less disruptive to the benthic environment than environmental dredging (Palermo

7 et al., 1998; NRC, 2001, ITRC, 2014). Conventional or passive capping is a remediation

8 technique in which contaminated sediment is covered with a layer (cap) of clean, inert material

9 such as sand, soil, or sediment to physically isolate the contaminants and prevent them from

10 being released to the water column and accumulated by biota. The cap increases the path length

11 that contaminants have to travel to be released to the water, decreases the resuspension of

12 contaminated particles, and provides a cleaner habitat for benthic fauna. An example of

13 successful remediation with a passive cap is Bellinghan Bay, WA, a shallow intertidal lagoon

14 contaminated with Hg (ITRC, 2014). In contrast, active capping and in situ treatment involve

15 the application of chemically reactive amendments to the sediment surface that bind organic and

16 inorganic contaminants, thereby reducing pore water contaminant concentrations and

17 contaminant bioavailability (Knox et al., 2008; Paller and Knox, 2010; Ghosh et al., 2011;

18 Dixon and Knox, 2012; Knox et al., 2012 and 2014). In active capping these amendments are

19 applied as a discrete layer on the sediment surface; whereas in in situ treatment they are

20 broadcast over the sediment surface or mixed into the surficial layer of sediment. Amendments

21 used in active capping include activated carbon, phosphate materials (e.g., apatite), zeolite,

22 organoclays, bentonite, and others based on the proven ability of these materials to sequester

23 metals, or organic contaminants (Ghosh et al., 2011; Knox et al., 2012). 

sources will be completely eliminated from aquatic environments. As a result, remediated sediments may be exposed to continued inputs from permitted discharges, upstream

4 contaminated sites, or stormwater discharge resulting in recontamination that can slow or reverse 5 recovery associated with sediment remediation efforts. This is of concern to environmental

6 regulators in the U.S. EPA and U.S. Department of Defense (DoD), who have expressed the need 7 for a better understanding of how releases from ongoing sources relate to recontamination of the 8 sediment bed (SERDP and ESTCP, 2012). This knowledge will contribute to more rigorous risk 9 management that incorporates the resilience of remedies in the face of ongoing contamination 10 into the criteria for remedy selection. The Comprehensive Environmental Response, 11 Compensation, and Liability Act (CERCLA) sediment cleanup actions, and Clean Water Act 12 (CWA)-related Total Maximum Daily Loads (TMDL) actions provide legal context for dealing 13 with the environmental challenges posed by sediment recontamination (SERDP and ESTCP, 14 2012). The recontamination of previously remediated contaminated sediments has the potential 16 to negate expensive remedial actions by producing a polluted habitat zone that overlies 17 remediated sediments. This is a challenge to all remedial approaches, but the severity of the 18 problem may be affected by the type of remediation that has been undertaken. Influxes of 19 contaminants can be expected to degrade the benthic environment as contaminants progressively 20 accumulate in areas previously remediated by environmental dredging or conventional capping 21 with inert materials. However, we hypothesize that the sequestering agents used in active caps 22 or in in situ treatment will interact with incoming contaminants, thereby reducing their 23 bioavailability and toxicity. In this paper, we provide novel results that address the research gap 
1 related to the effects of ongoing sources of contamination on different technologies for the

2 remediation of contaminated sediments. This paper complements previous work on the

3 development of active caps for contaminated sediments (Knox et al., 2008, 2012, and 2014).

4 However, neither active caps nor other remediation technologies have been evaluated for their

5 effectiveness and environmental impact when confronted with ongoing contamination.

\section{2. Materials and methods}

\section{$7 \quad$ 2.1. Experimental setup}

The experimental setup included 30 flow-through mesocosms designed to test the effects

9 of dissolved and particulate metal influxes on selected cap materials present in different

10 thicknesses (Figure 1). Each mesocosm consisted of a $20 \mathrm{~cm}$ wide, $41 \mathrm{~cm}$ long, $43 \mathrm{~cm}$ high

11 custom built acrylic aquarium with an acrylic lid. Homogenized clean sediment was placed in

12 the bottom of 27 of the mesocosms to produce a $12.5 \mathrm{~cm}$ layer.

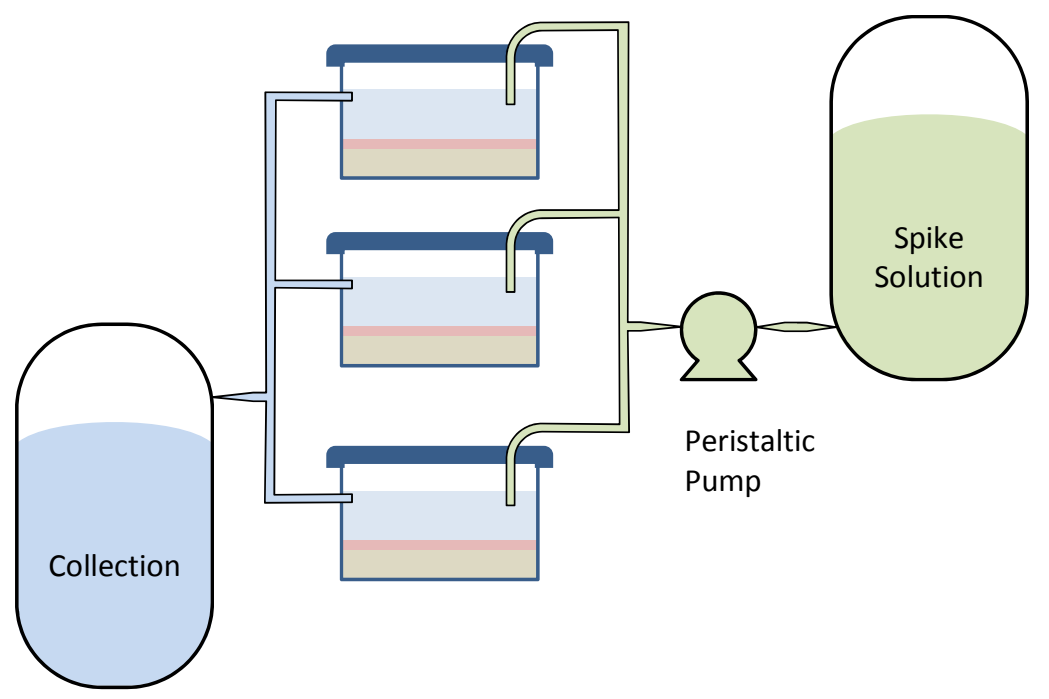




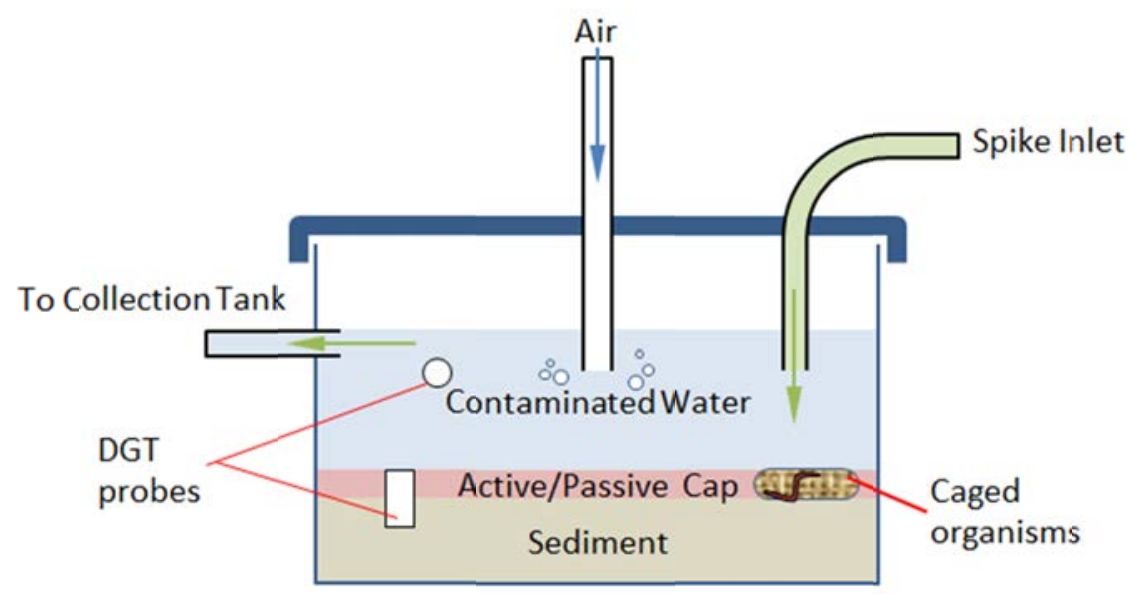

2 Figure 1. Mesocosm experimental design.

3

The mesocosms represented different cap compositions, cap thicknesses, controls with sediment but without caps, and controls without sediment or caps (spike solution only). Passive caps consisted of sand; materials used in active caps included apatite (North Carolina rock phosphate), organoclay (MRM from CETCO), activated carbon, and locally collected, subsurface red clay sediment. Apatite had a pH of $7.8\left(1: 1\right.$ solid to $\left.\mathrm{H}_{2} \mathrm{O}\right)$, cation exchange capacity (CEC) of $218 \mathrm{~g} \mathrm{~kg}^{-1}$, Ca content of $15.2 \%$, and was composed mostly of hydroxyapatite (X-ray diffraction analyses of apatite are presented in Chlopecka and Adriano (1996) and Knox et al. (2003). Organoclay (MRM) is a sulfur-impregnated organophilic clay granular filtration medium that adsorbs non-aqueous phase liquids (NAPL) and dissolved low-solubility organics (CETCO, 2012). It also sequesters mercury and arsenic from water. Activated carbon was bone char from Norit America, Inc., which is produced from animal bones. It differs from plant derived activated carbon in containing both carbon surface area and hydroxyapatite lattice surface area, which makes bone char very effective for metal removal. Clay sediment had a $\mathrm{pH}$ 
1 of 5.5 , a surface area of $15.07 \mathrm{~m}^{2} \mathrm{~g}^{-1}$, and included minerals rich in Fe (goethite and hematite)

2 that could effectively sorb some metals.

There were 10 treatments: a control consisting of spike solution only (C); uncapped sediment (SED); $2.5 \mathrm{~cm}$ sand cap (S-1); $5.0 \mathrm{~cm}$ sand cap (S-2); $2.5 \mathrm{~cm}$ silty clay cap (SC); 2.5 cm apatite cap (A-1); $5.0 \mathrm{~cm}$ apatite cap (A-2); activated carbon treatment (AC, 5\% by dry

6 weight broadcasted on the sediment surface); $2.5 \mathrm{~cm}$ organoclay cap (MRM); and a $2.5 \mathrm{~cm}$ cap

7 composed of a mixture of $60 \%$ apatite, $5 \%$ activated carbon, and 35\% organoclay MRM (MC).

8 Each treatment was represented by three replicates, with treatments randomly allocated among

9 mesocosms. Sediments were permitted to equilibrate for two weeks, and the cap materials were

10 placed on top of the sediment. The treated and untreated sediments were then saturated and the

11 tanks were filled with deionized water and equilibrated for four weeks prior to receiving spike

12 solution consisting of deionized water with dissolved metals. A single 50 liter reservoir supplied

13 the mesocosms with a continuous inflow $\left(0.3 \mathrm{ml}\right.$ minute $\left.\mathrm{e}^{-1}\right)$ of spike solution that contained 0.5

$14 \mathrm{mg} \mathrm{L}{ }^{-1}$ each of arsenic (As), chromium (Cr), cadmium (Cd), cobalt (Co), copper (Cu), nickel

$15(\mathrm{Ni})$, lead $(\mathrm{Pb})$, selenium $(\mathrm{Se})$, and zinc $(\mathrm{Zn})$. A single multi-channel peristaltic pump that

16 withdrew water from the reservoir uniformly delivered the spike solution to all mesocoms during

17 the 2520 hour experiment.

An airstone diffuser was placed in each mesocosm to suspend particulate matter, thereby simulating field conditions in which particle-bound metals are a significant source of

20 recontamination (Figure 1 ).

\subsection{Surface water sampling}

Surface water samples (10 ml each) were collected daily for the first 10 days and weekly thereafter. Samples for dissolved metals were filtered using a $0.45 \mu \mathrm{m}$ pore diameter membrane 
1

2

filter; samples for total recoverable metals were not filtered. All samples were acidified with nitric acid to $\mathrm{pH}<2$. Metal concentrations in filtered and unfiltered samples were analyzed by inductively coupled plasma-mass spectrometry (ICP-MS) using a NexION 300X mass spectrometer (Perkin Elmer, Inc.) in accordance with the quality assurance and quality control protocols of EPA method 6020A (U.S. EPA, 2007). Surface water in all tanks was monitored for dissolved oxygen, temperature, electrical conductivity, $\mathrm{pH}$, and turbidity. Calcium hardness was measured by ethylenediaminetetraacetic acid (EDTA) titration (Hach, 2013).

\subsection{Toxicity and bioaccumulation testing}

The California blackworm Lumbriculus variegatus is a common freshwater benthic oligochaete that burrows in shallow sediments. Blackworms were obtained from a commercial supplier (California Blackworm Co.). Three grams of blackworms were drained of excess water, and placed in each of thirty $12 \mathrm{~cm}$ long, $2 \mathrm{~cm}$ inner diameter screened cages for deployment into the experimental mesocosms. Each mesocosm received one cage, which was filled to $40-50 \%$ of maximum volume with cap material or sediment taken from just below the solid-water interface.

The cages were partly (50\%) buried in a horizontal position for 10 days and retrieved at hour 2040 of the 2520 hour experiment. Living blackworms were removed from the cages and weighed in aggregate to determine percent recovery (initial weight/final weight x 100), which was used as an estimate of survival.

Blackworms that remained alive were analyzed in aggregate for whole-body metal concentrations. They were rinsed, depurated in clean water for six hours, drained of excess water, and quick frozen prior to lyophilization. Metal analyses were conducted on $50 \mathrm{mg}$ samples of freeze-dried tissue digested with $1 \mathrm{~mL}$ of $\mathrm{H}_{2} \mathrm{O}_{2}$ (30\%) and $3 \mathrm{~mL}$ of trace metal grade nitric 
1 acid at $85{ }^{\circ} \mathrm{C}$. After digestion, the samples were analyzed by ICP-MS using the protocols listed

2 above (U.S. EPA, 2007).

3 2.4. Assessment of cap effectiveness by diffusive gradients in thin films (DGT) probes

$4 \quad$ Diffusive gradient in thin films (DGT) is a passive sampling technology that consists of a

5 collection gel-layer with a medium that selectively binds to the contaminant of interest and a

6 diffusion gel-layer that selectively admits analyte molecules (Davison and Zhang, 1994). Chelex

7100 sediment DGT probes (purchased from DGT Research Ltd, Lancaster, UK) were

8 deoxygenated before deployment. One probe was deployed for 24 hours within each mesocosm

9 at 2016 hours by inserting it vertically to measure metal levels in the cap and underlying

10 sediment layers, which were divided into A $(0-2.5 \mathrm{~cm})$, B $(2.5-5.0 \mathrm{~cm})$, and C $(5-7.5 \mathrm{~cm})$.

11 The probes were rinsed upon retrieval, and the resin-gel layer from each probe was removed and

12 divided into sections representing each layer. Each section was immersed in $1 \mathrm{ml}$ of $1 \mathrm{M} \mathrm{HNO}_{3}$

13 for 24 hours, which was diluted with deionized water prior to analysis by ICP-MS. The masses

14 of metal accumulated on the resin gel layers and the DGT concentrations of metals in the

15 sediment ( $\left.\mathrm{C}_{\mathrm{DGT}}\right)$ were calculated as shown in Zhang and Davison (1995) and Zhang et al.

16 (2001).

tube coring device to measure sediment $\mathrm{pH}$. The cores from sediment only and activated carbon treatments were split into three layers: A: 0-2.5 cm, B: 2.5-5.0 cm, and C: below $5.0 \mathrm{~cm}$. The cores from treatments with caps were split into a cap layer and three layers of sediment beneath

21 the cap (A: 0-2.5 cm, B: 2.5-5 cm, and C: below $5.0-7.5 \mathrm{~cm}$ ). The $\mathrm{pH}$ was determined from a

$22 \quad 1: 1 \mathrm{solid} /$ water equilibrium solution.

$23 \quad$ 2.5.Statistical analysis 
The significance $(\mathrm{p}<0.05)$ of differences in metal concentrations in blackworm tissues

2

3

4 7 probes. among treatments was assessed with one-way analysis of variance (ANOVA) followed by pairwise Holm-Sidak tests. Data were $\log _{10}(\mathrm{X}+1)$ transformed to better approximate the assumptions of normality and homoscedasticity. Test results are presented as geometric means calculated by back-transformation. Pearson correlations were calculated between metal concentrations in blackworm tissues and metal concentrations in sediment measured by DGT

\section{Results and discussion}

The treatments were evaluated based on the following criteria: 1) surface water properties, 2) dissolved and particulate metal concentrations in surface water, 3) toxicity to

11 Lumbriculus, 4) bioaccumulation of metals by Lumbriculus, and 5) metal concentrations 12 measured by diffusive gradients in thin films (DGT) probes.

\section{$13 \quad 3.1$ Surface water properties}

Electrical conductivity (EC) was consistent throughout the 2520 hour experiment and was highest in the mesocosms with MRM caps followed by the mesocosms with mixed

16 amendments (Figure 2). Turbidity was highest in the mesocosms with uncapped sediments,

17 activated carbon treatments, and silty clay caps because these mesocosms contained easily

18 suspended fine particles (Figure 2). Surface water $\mathrm{pH}$ was affected by the $\mathrm{pH}$ of the spike

19 solution and the cap materials. The highest average $\mathrm{pH}$ was in treatments with activated carbon

20 followed by apatite and MC caps. Only the mesocosm with organoclay MRM caps showed

21 significant changes over time, with $\mathrm{pH}$ decreasing from about 6.6 to 4.0 (Figure 2). Dissolved

22 oxygen concentrations and temperatures (average of about $18^{\circ} \mathrm{C}$ ) were similar among treatments

23 and stable throughout the experiment. Some amendments (e.g., apatite and MRM) increased the 
1 water calcium carbonate hardness from less than 5 (control and sand cap treatments) to about $2180 \mathrm{mg} \mathrm{L}^{-1}$ (Figure 3).
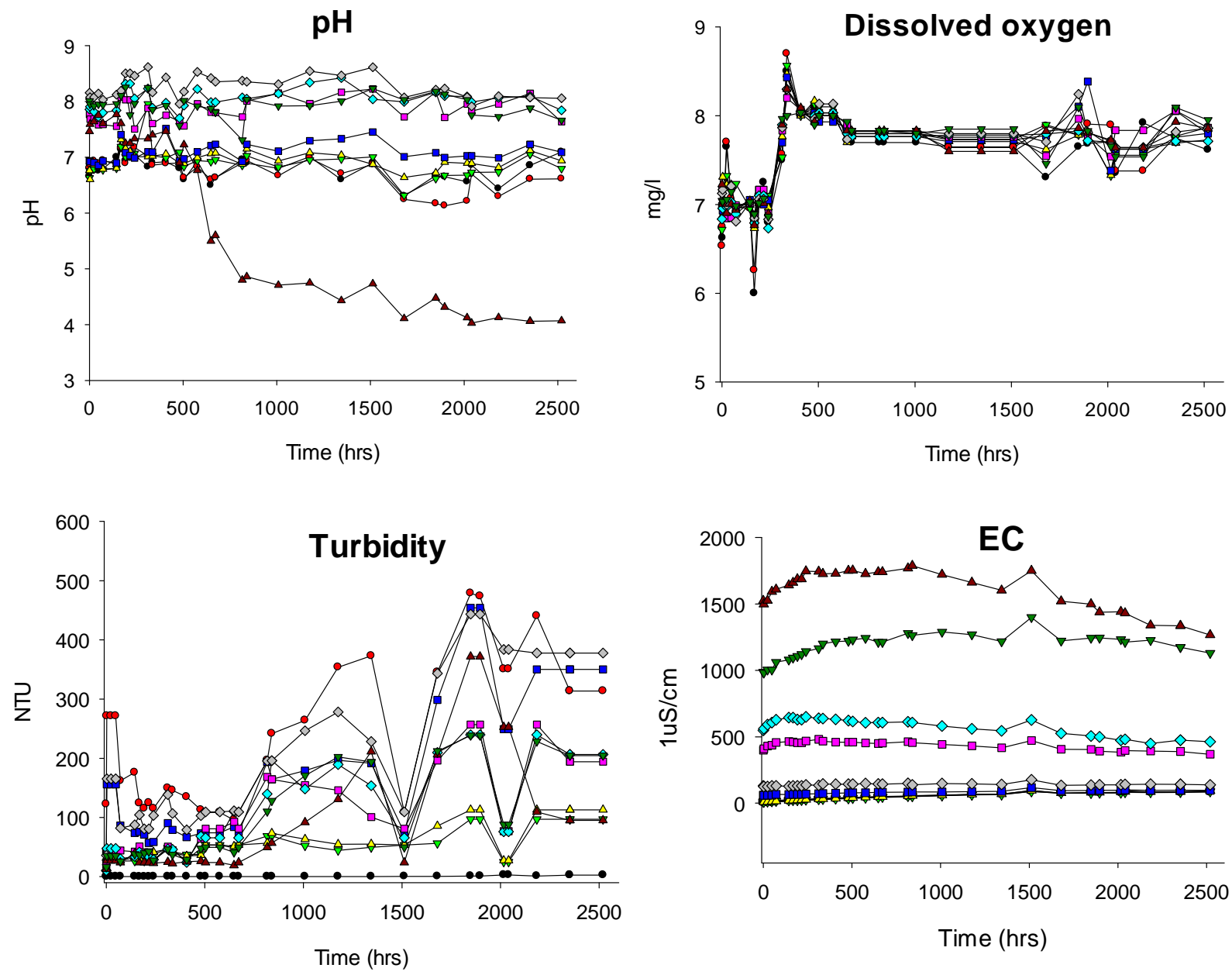

$\longrightarrow$ Spike
$\square$ Sediment
$\square$ Sand -1
$\square$ Sand -2
$\square$ Silty clay
$\square-$ Apatite -1
$\neg$ Apatite -2
$\multimap$ Activated carbon
$\square$ MRM
$\square$ MC

6 Figure 2. Water quality over time for each treatment; average results for $\mathrm{pH}$, dissolved oxygen 7 turbidity, and electrical conductivity (EC) $(n=3)$. 


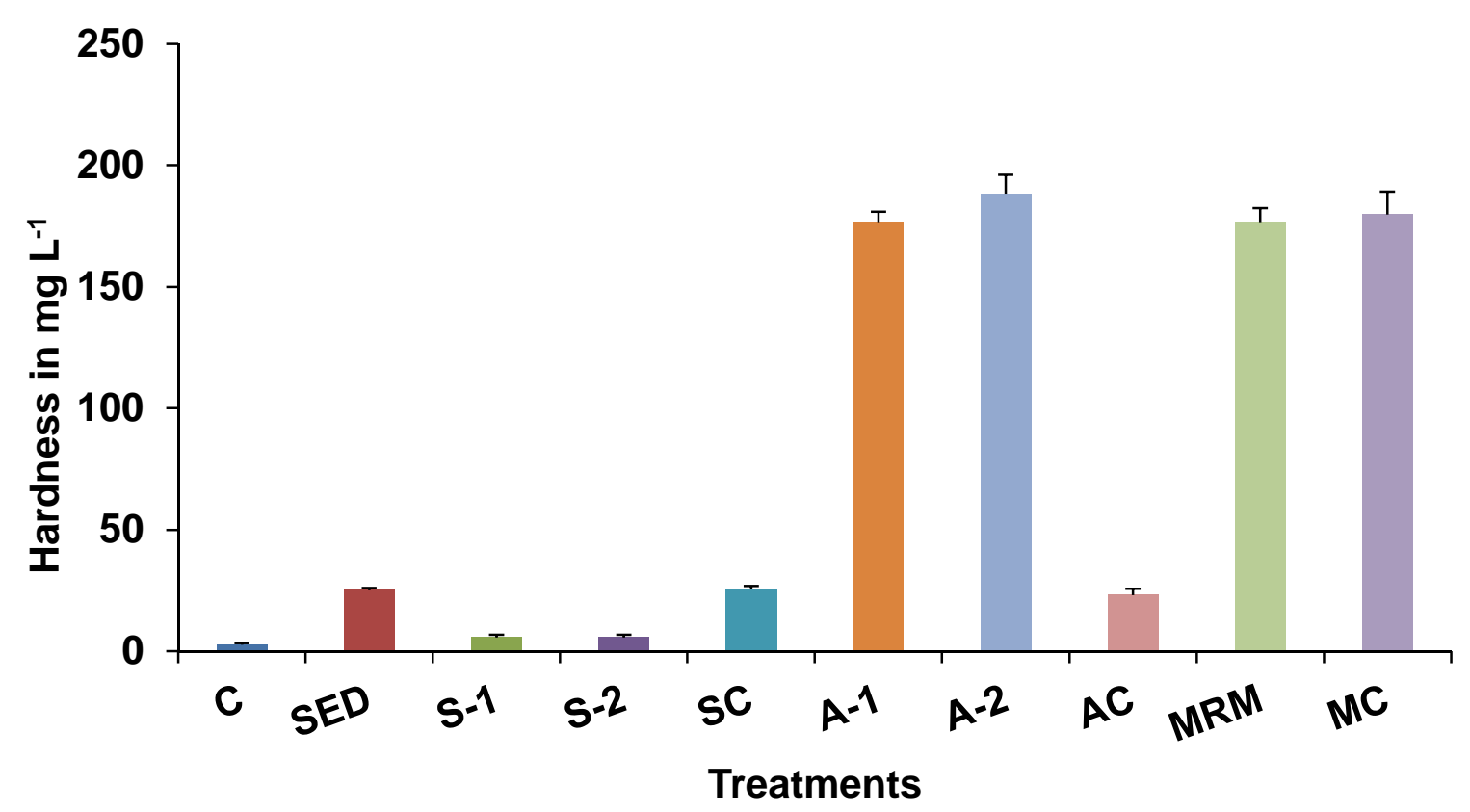

1

2

8

Figure 3. Hardness of surface water $\left(\mathrm{mg} \mathrm{L}^{-1}\right.$ ) for each treatment at 2520 hours; spike solution only (C), uncapped sediment (SED), sediment with passive sand caps (S-1: $2.5 \mathrm{~cm}, \mathrm{~S}-2: 5 \mathrm{~cm})$, and sediment with several types of active caps (SC: $2.5 \mathrm{~cm}$ silty clay, A-1: $2.5 \mathrm{~cm}$ apatite , A-2: $5.0 \mathrm{~cm}$ apatite, AC: activated carbon treatment, MRM: $2.5 \mathrm{~cm}$ organoclay, and MC: $2.5 \mathrm{~cm}$ mixture of active amendments).

\subsection{Effect of ongoing contaminant influx on metal concentrations in surface water}

The concentration of each metal in the spike solution was about $0.5 \mathrm{mg} \mathrm{L}^{-1}$ as indicated by ICP-MS. Maintaining these concentrations required keeping the $\mathrm{pH}$ of the spike below 7.0 to prevent metals from precipitating. The effects of the treatments on metal concentrations in surface water are shown in Figures 4 and 5. Electrons neutralize protons (i.e., $\mathrm{H}^{+}$) in many naturally-occurring reactions (Dragun, 1998), so the fixation of elements in sediment and cap materials was dependent upon Eh and $\mathrm{pH}$. Because the Eh of the water column was stable for all treatments and above 0.0, dissolved and particulate metal concentrations in the water column 
1 were mostly dependent on $\mathrm{pH}$. Other factors that likely affected the chemisorption of metals in

2 this experiment included electronegativity, electrostatic forces between metal ions and

3 sediment/cap material surfaces, surface complexation reactions, charge-to-radius ratios, and

4 hydrolysis constants (McBride, 1994; Shi et al., 2009).

At 2520 hours, the average dissolved arsenic concentration in the mesocosms with active

6 caps was about $70 \mu \mathrm{g} \mathrm{L}{ }^{-1}$ compared with $250 \mu \mathrm{g} \mathrm{L}-1$ in the control mesocosms (spike solution

7 only) and $114 \mu \mathrm{g} \mathrm{L}^{-1}$ in the mesocosms with passive caps (Figure 4). Dissolved As

8 concentrations in mesocosms with active caps (especially MC and A) were lower than in

9 mesocosms with passive caps and control mesocosms (Figure 4). Arsenic concentrations were

10 about 50\% lower in the control treatment than in the spike solution, likely due to As precipitation

11 as $\mathrm{As}_{2} \mathrm{O}_{3}$. Dragun (1998) reported that particle bound As predominates under Ehs above 0.0 and

12 at $\mathrm{pH} 7$.

Dissolved Cd increased over time in all treatments, but the increases were much greater

14 in the control mesocosms and mesocosms with passive caps (Figure 5). At 2520 hours, average

15 Cd concentrations in surface water were less than $100 \mu \mathrm{g} \mathrm{L}^{-1}$ in the mesocosms with active caps

16 (except MRM) compared with more than $300 \mu \mathrm{g} \mathrm{L}^{-1}$ in the mesocosms with passive caps and 500

$17 \mu \mathrm{g} \mathrm{L}^{-1}$ in the control mesocosms (Figures 4 and 5). Total Cd concentrations were relatively high

18 in the mesocoms with MRM caps due to low pH (Figure 2). Particle bound Cd was a small

19 fraction of total Cd in all treatments (Figure 4). Cadmium is soluble over a wide range of pHs

20 (Adriano, 2001), so Cd concentrations in the control treatment were similar to Cd concentrations

21 in the spike solution (Figure 4). Also, the relatively low metal electronegativity of Cd (1.69)

22 tended to reduce the specific adsorption of this ion resulting in a relatively high proportion of Cd

23 being dissolved. 

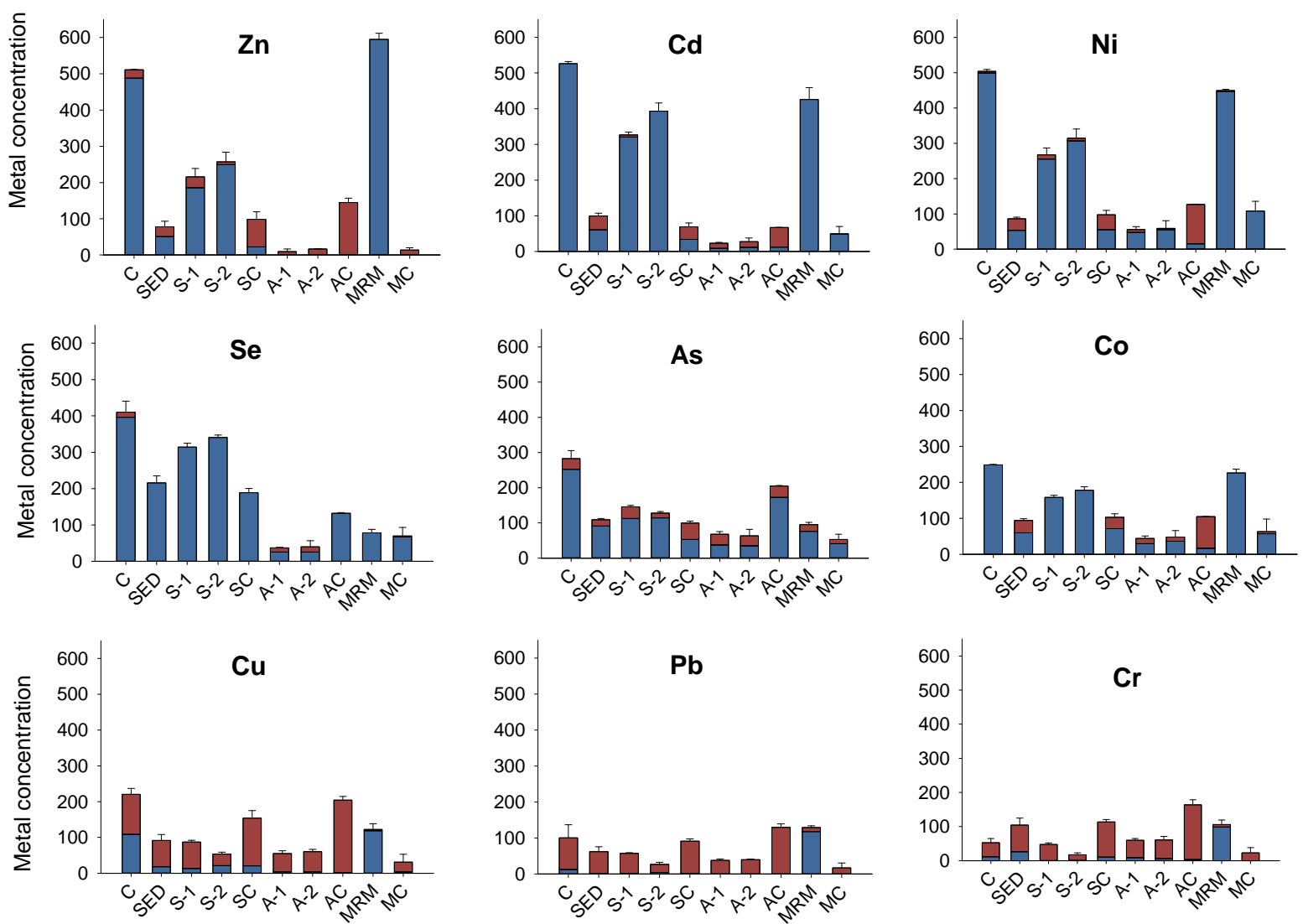

\section{Dissolved $\left(\mu \mathrm{g} \mathrm{L}^{-1}\right) \rightleftharpoons$ Particulate $\left(\mu \mathrm{g} \mathrm{kg}^{-1}\right)$}

Figure 4. Average surface water concentrations of metals in mesocosms with no sediment, spike solution only (C), uncapped sediment (SED), sediment with passive sand caps (S-1: 2.5 cm cap, S-2: $5 \mathrm{~cm}$ cap), and sediment with several types of active caps (SC: $2.5 \mathrm{~cm}$ silty clay cap, A-1: $2.5 \mathrm{~cm}$ apatite cap, A-2: $5.0 \mathrm{~cm}$ apatite cap, AC: activated carbon treatment, MRM: $2.5 \mathrm{~cm}$ organoclay cap, and MC: $2.5 \mathrm{~cm}$ mixed amendment cap) at 2520 hours. 

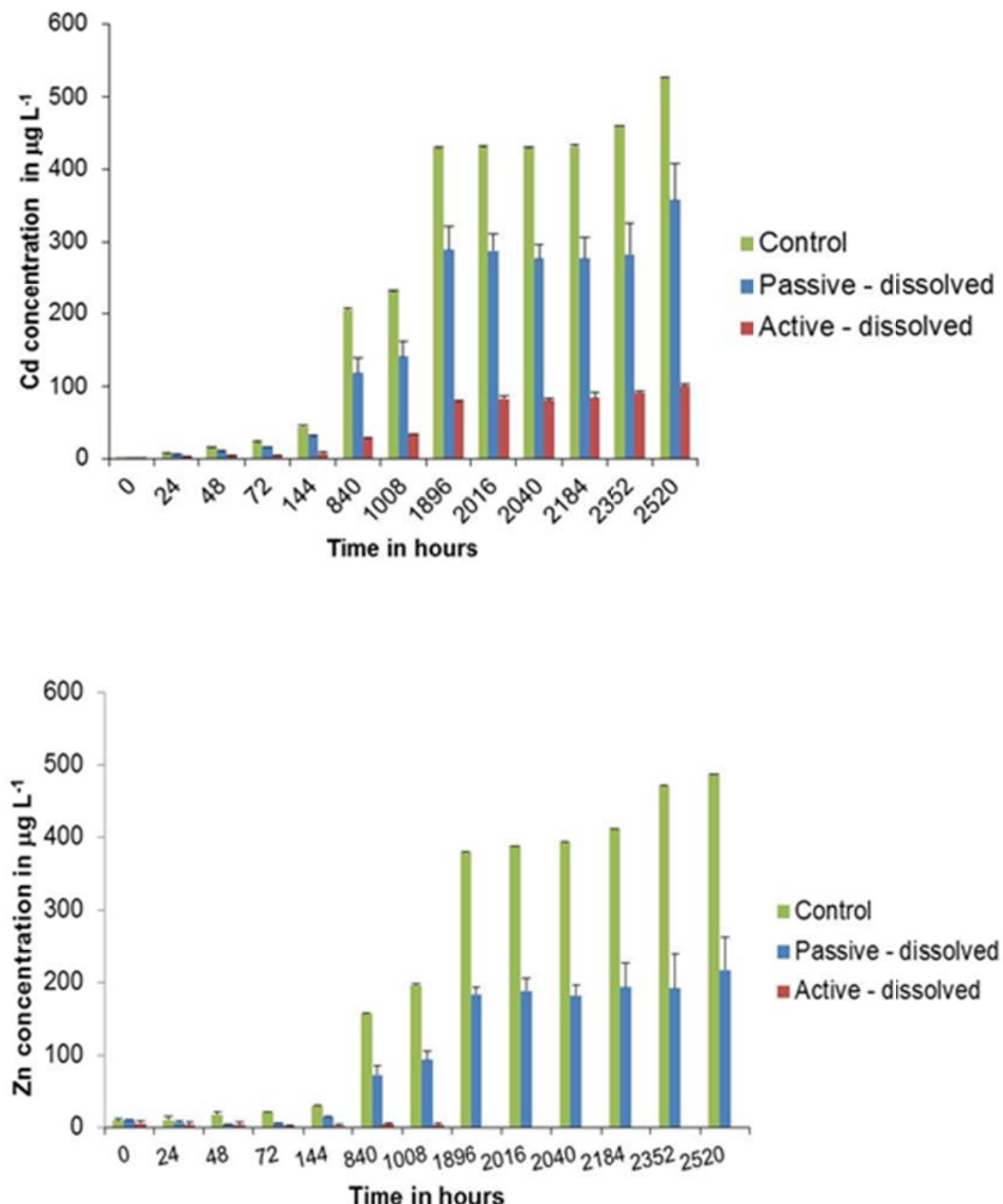

3

4 Figure 5. Average surface water concentrations of dissolved $\mathrm{Cd}$ and $\mathrm{Zn}$ in mesocosms with

5 passive caps ( $\mathrm{n}=6$ for $2.5 \mathrm{~cm}$ sand cap and $5.0 \mathrm{~cm}$ sand cap), active caps ( $\mathrm{n}=12$ for the $2.5 \mathrm{~cm}$

6 apatite cap, $5.0 \mathrm{~cm}$ apatite cap, activated carbon treatment, and $2.5 \mathrm{~cm}$ mixed amendment cap),

7 and without caps or sediment (control) (n=2) over 2520 hours. 
Dissolved Se in the control mesocosms was $400 \mu \mathrm{g} \mathrm{L}^{-1}$ at 2520 hours and was also

relatively high in the treatments with passive sand caps (Figure 4). Levels were substantially lower in the mesocosms with active caps, especially apatite caps (under $50 \mu \mathrm{g} \mathrm{L}{ }^{-1}$ ). At 2520 hours, most Se was dissolved in all treatments (Figure 4). Although relatively ineffective at removing divalent metals such as $\mathrm{Zn}, \mathrm{Cd}$, and $\mathrm{Ni}$, MRM caps were about as effective as apatite caps at removing Se and As from the surface water. MRM is specifically designed for the removal of $\mathrm{Hg}$ and As rather than other elements (CETCO, 2012).

Like Cd, Zn is very mobile over a wide range of pHs (Adriano, 2001) and has relatively low electronegativity (1.65) (McBride, 1994); therefore, Zn concentrations in the control treatment were comparable to those in the spike solution. Average dissolved $\mathrm{Zn}$ increased over time in the control mesocosms and mesocosms with passive caps, reaching $500 \mu \mathrm{g} \mathrm{L}^{-1}$ in the former and nearly $200 \mu \mathrm{g} \mathrm{L} \mathrm{L}^{-1}$ in the latter (Figure 5). In contrast, average dissolved $\mathrm{Zn}$

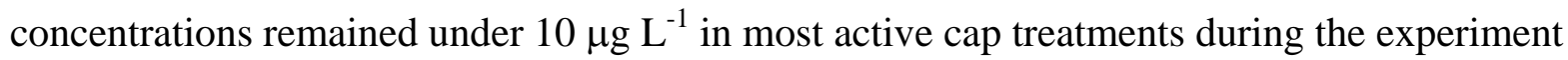
(Figure 5). High dissolved Zn concentrations in the MRM treatment were likely the result of low $\mathrm{pH}$ (about 4.0; Figure 2) that facilitated metal dissolution. The lowest average total Zn concentrations were in mesocosms with apatite caps (A) and multiple amendment caps (MC). Most of the $\mathrm{Zn}$ in these mesocosms was particle-bound, and very little was in the more bioavailable dissolved phase (Figure 4). Ma et al. (1995) and Wright et al. (1995) have reported that the interaction between apatite and metals in solution is controlled by the precipitation of various phosphate phases, soption, and isomorphic substitution.

Nickel behaved similarly to Cd, Co, Zn, and Se (Figure 4). However, Cr, Cu and Pb total concentrations in the control treatment were lower than concentrations in the spike solution (500 $\mu \mathrm{g} \mathrm{L}{ }^{-1}$ ) suggesting the possibility of co-interference among these elements and solid phase 
1 partitioning through sorption and precipitation. This is consistent with other reports; e.g., Dragun

2 (1998) reported that $\mathrm{Pb}$ is generally in particulate-bound forms such as $\mathrm{PbCO}_{3}$ and $\mathrm{PbO}$ above

$3 \quad$ Eh 0.0 and $\mathrm{pH} 4$.

$4 \quad$ 3.3. Toxicity and bioaccumulation

Average percent survival of Lumbriculus for the 10 day test was $0 \%$ in the control

6 mesocosms, $0 \%$ in the mesocosms with passive (sand) caps, $10 \%$ in the mesocosms with

7 uncapped sediment, and 65-80\% in the mesocosms with active caps suggesting that the latter can

8 protect benthic organisms from ongoing contamination (Figure 6). High water hardness likely

9 contributed to the relatively low mortality of test organisms in the treatments with apatite,

10 organoclay, and MC (Figure 3). The acute toxicity of many elements (e.g., Cd, Cr, Cu, Ni, Pb,

11 and Zn) depends on water hardness, with toxicity diminishing as hardness increases (U.S. EPA,

12 2016). In contrast, mortality was high in treatments with low hardness (e.g., sediment only or

13 sand) (Figures 3 and 6). Therefore, evaluation of cap materials should be based not only on their

14 ability to sequester metals but also on their indirect effects on water properties (e.g., hardness)

15 that can influence metal bioavailability and toxicity.

16 Surviving Lumbriculus were analyzed for whole-body metal concentrations, which were

17 compared with background concentrations measured in Lumbriculus received from the supplier.

18 Background concentrations of $\mathrm{Co}, \mathrm{Cd}, \mathrm{Cr}, \mathrm{Ni}, \mathrm{Pb}$, and Se were $<2.0 \mathrm{mg} \mathrm{kg}^{-1}$, similar to those

19 reported by Piol et al. (2006). Following 10 days of exposure, these metals increased to 20 - 150

$20 \mathrm{mg} \mathrm{kg}^{-1}$ in Lumbriculus from mesocosms with uncapped sediment but remained under $10 \mathrm{mg}$ 21 


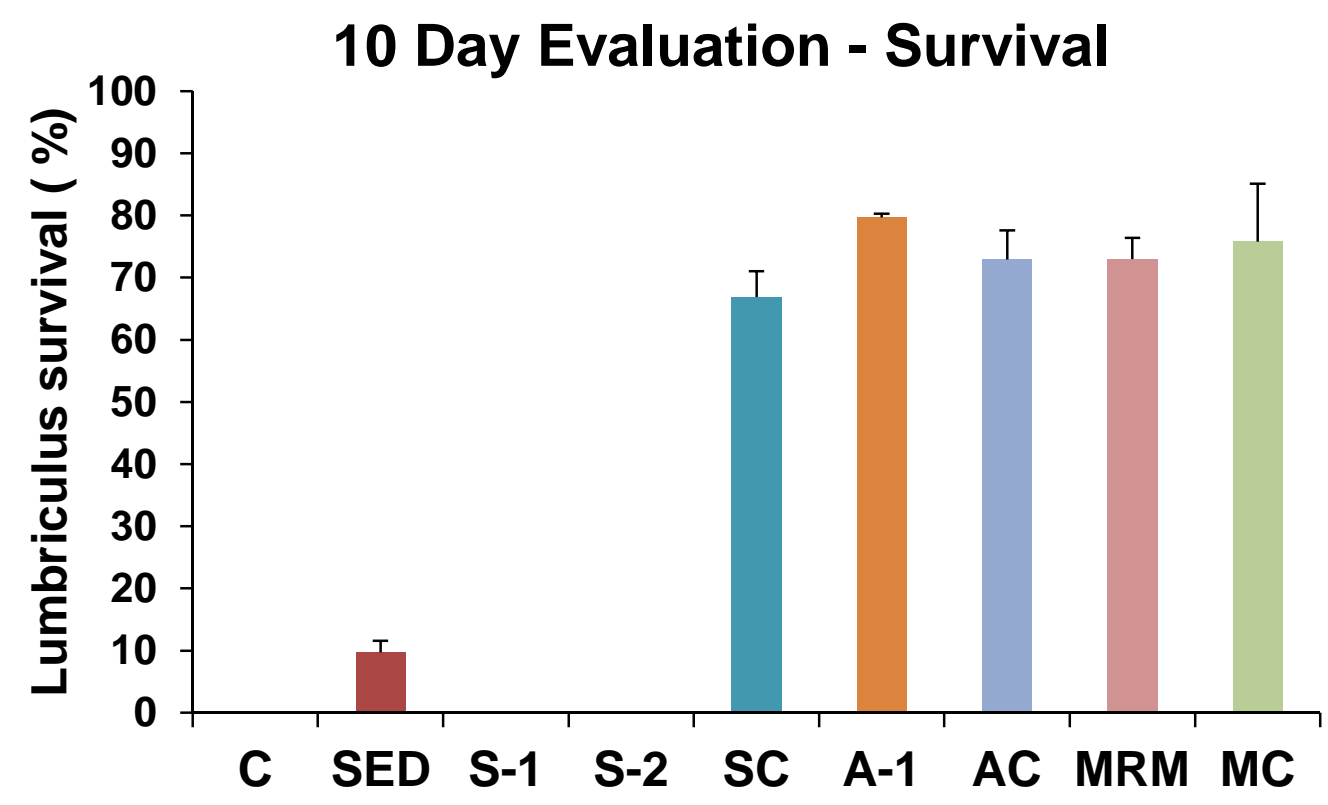

1

2 Figure 6. Average survival of Lumbriculus variegatus after 10 day toxicity tests conducted in

3 mesocosms receiving water spiked with dissolved metals. Mesocosm treatments included spike

4 solution only (C), uncapped sediment (SED), sediment with sand caps (S-1: $2.5 \mathrm{~cm}$ and S-2: 5

$5 \mathrm{~cm}$ ), and sediment with active caps (SC: $2.5 \mathrm{~cm}$ silty clay, A-1: $2.5 \mathrm{~cm}$ apatite, AC: activated

6 carbon, MRM: $2.5 \mathrm{~cm}$ organoclay, and MC: $2.5 \mathrm{~cm}$ mixture of active amendments). Error bars

7 are standard deviations $(\mathrm{n}=3)$.

8

$9 \mathrm{~kg}^{-1}$ in Lumbriculus from most mesocosms with active caps (Figure 7). Differences between

10 mesocosms with active caps and mesocosms with untreated sediment were statistically

11 significant $(\mathrm{p}<0.05)$. Although all active caps were effective at reducing metal uptake, there

12 were significant differences among cap types, with the most effective caps varying among metals

13 (Figure 7). Differences in Lumbriculus tissue concentrations between active caps and untreated 
1 sediment were less prominent for As and $\mathrm{Cu}$ than for the previously discussed metals but were

2 statistically significant except for $\mathrm{Cu}$ in the silty clay cap (Figure 7). The concentrations of most

3 metals in Lumbriculus from the active cap treatments were higher than background

4 concentrations, but these differences were not always statistically significant (Figure 7).

5 Background levels of $\mathrm{Zn}$ in Lumbriculus (about $200 \mathrm{mg} \mathrm{kg}^{-1}$ ) were higher than for the other

6 metals. These levels were comparable to those in the mesocosms with active caps and

7 significantly lower than in the mesocosms with uncapped sediment (about $700 \mathrm{mg} \mathrm{kg}^{-1}$ ) (Figure 8 7).

Kwon et al. (2010) reported that the sorbent material, Thiol-SAMMS, was able to reduce 10 the uptake of Cd by Lumbriculus from beakers of contaminated sediment by up to $98 \%$. These

11 results are comparable to those in our mesocosms with apatite and mixed amendment caps

12 (Figure 7) despite more challenging conditions of exposure involving the continuous influx of 13 contamination via the overlying water column. 

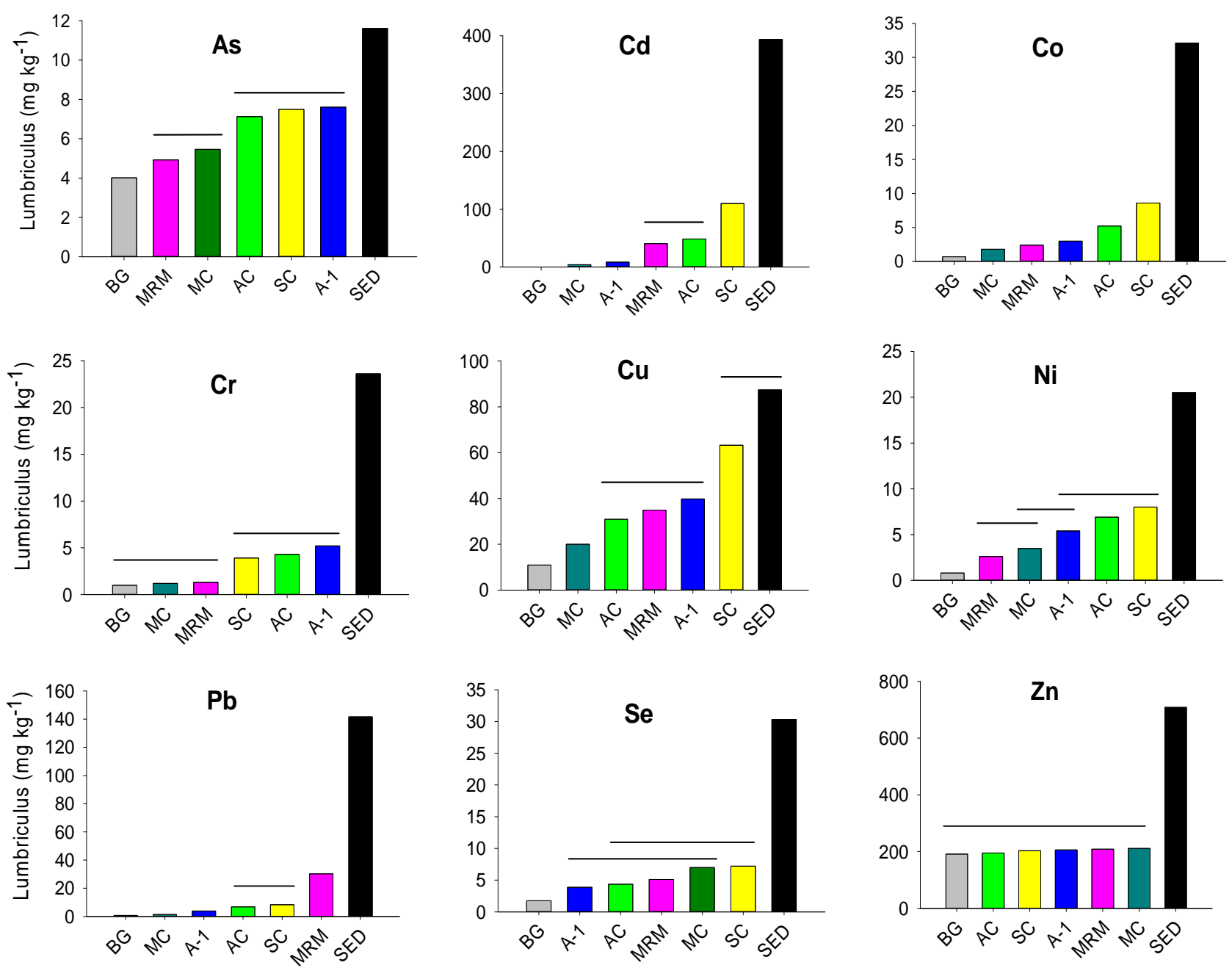

3 Figure 7. Analysis of variance of differences in Lumbriculus variegatus metal concentrations

4 (whole body, 10 day exposure) among sediment treatments (BG =background, AC: activated

5 carbon, SC: silty clay cap, A: apatite cap (2.5 cm thick), MRM: organoclay MRM cap, MC:

6 mixture of active amendments, SED: untreated sediment). Geometric means connected by the

7 same line are not significantly different at $p<0.05$. 


\subsection{Assessment of cap effectiveness by diffusive gradients in thin films (DGT) probes}

DGT probes have the theoretical advantage of selectively measuring metal phases that are bioavailable and potentially toxic (Davison and Zhang 1994). DGT gel probe samplers were used to determine the effects of the cap materials on the bioavailable pools of metals in the caps and sediments. Only $\mathrm{Cd}, \mathrm{Co}, \mathrm{Cu}, \mathrm{Ni}, \mathrm{Pb}$, and $\mathrm{Zn}$ (Figures 8 and 9) could be measured by the chelex 100 sediment DGT probes. Generally, metal concentrations in the apatite and MC cap layers and in the upper layer of sediment treated with activated carbon were very low compared with metal concentrations in the passive sand and silty clay cap layers and much lower than in the surface layer of sediment in the mesocosms without caps (Figures 8 and 9). Lower sediment metal levels in apatite, activated carbon, and MC treatments persisted deeper within the sediment profile, especially compared with uncapped sediment, which exhibited relatively high metals levels to a depth of $5.0 \mathrm{~cm}$ (examples are shown for Cd and Co, Figure 8). Metal levels, especially levels of $\mathrm{Ni}$, in treatments with MRM caps were higher than in the treatments with other active caps (Figure 9), probably because of low sediment pH (Figure 10). At 2520 hours the highest $\mathrm{pH}$ values were in mesocosms with apatite and MC caps followed by mesocosms with activated carbon (Figure 10). Mesocosms with organoclay MRM caps had the lowest $\mathrm{pH}$ values in the cap and the sediment below the cap (Figure 10).

The preceding results show that potentially bioavailable pool of metals was lower in the apatite and MC caps, in the sediments with activated carbon, and in the sediment layers underlying these treatments than in uncapped sediments or passive caps. Pearson correlations between metal concentrations in Lumbriculus and metal concentrations in the top $2.5 \mathrm{~cm}$ of sediment or cap materials (measured by DGT sediment probes) were generally strong (as high as $0.98)$ and significant $(\mathrm{p}<0.05)$ for all metals except zinc (Figure 9). These relationships suggest 
1 that metal concentrations in Lumbriculus were the result of uptake from the surrounding

2 sediment or cap and possibly the overlying water. Low metal concentrations in Lumbriculus

3 from the apatite, MC, and activated carbon treatments may have resulted from metal

4 sequestration by these amendments (Figure 7). Previous reports by Knox et al. (2012), Ghosh et

5 al (2011), and Ma et al. (1995) indicate that active amendments (e.g., apatite and activated

6 carbon) can reduce the bioavailable pool of contaminants in sediments. Dissolved metals that

7 precipitate on the sediment/cap surface or that are immobilized more deeply in the sediment

8 profile are generally biologically unavailable unless the re-enter the dissolved phase, which

9 facilitates transport through respiratory membranes (Campbell, 1995; McGreer et al., 2002). An

10 exception is metals that are ingested by sediment feeding organism, which may be released by

11 interactions with digestive fluids and again become available for biological uptake within the

12 organism (Fan and Wang, 2001). 

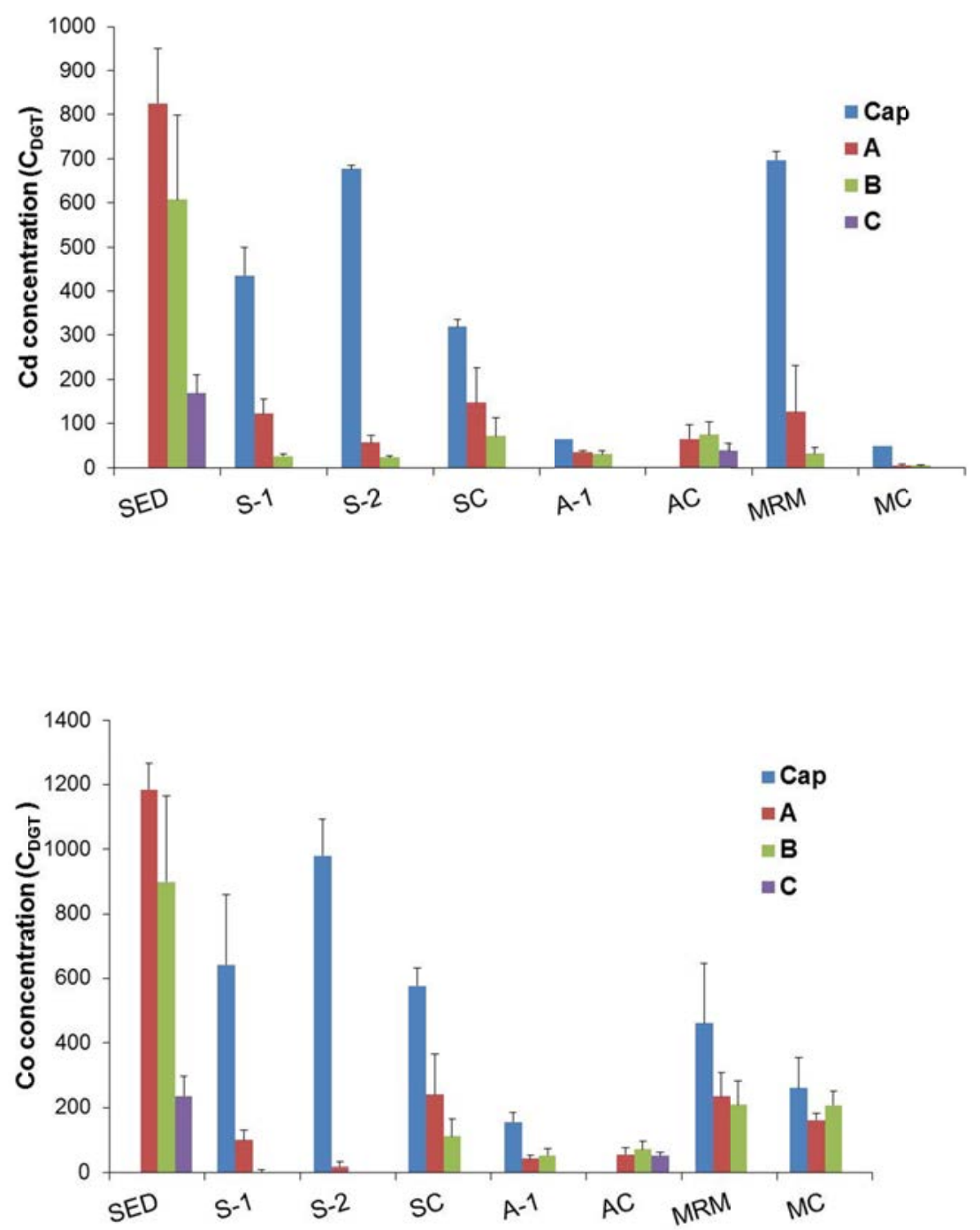

$4 \quad$ Figure 8. Cadmium (Cd) and cobalt (Co) concentrations $\left(\mu \mathrm{gg}^{-1}\right)$ measured by sediment DGT

5 probes $\left(\mathrm{C}_{\mathrm{DG}}\right)$ in cap materials and layers of sediment beneath the cap (layer $\mathrm{A}: 0-2.5 \mathrm{~cm}$, layer

6 B: $2.5-5.0 \mathrm{~cm}$, and layer C: $5-7.5 \mathrm{~cm}$ ). Treatments: uncapped sediment (SED), sediment with

7 passive sand caps ( $\mathrm{S}-1: 2.5 \mathrm{~cm}$ thick cap and $\mathrm{S}-2: 5 \mathrm{~cm}$ thick cap) and sediment with several

8 types of active caps (2.5 cm thick) (apatite A-1; silty clay - SC; activated carbon, no cap - AC;

9 organoclay - MRM:, and mixture of active amendments - MC) at 2040 hours. 

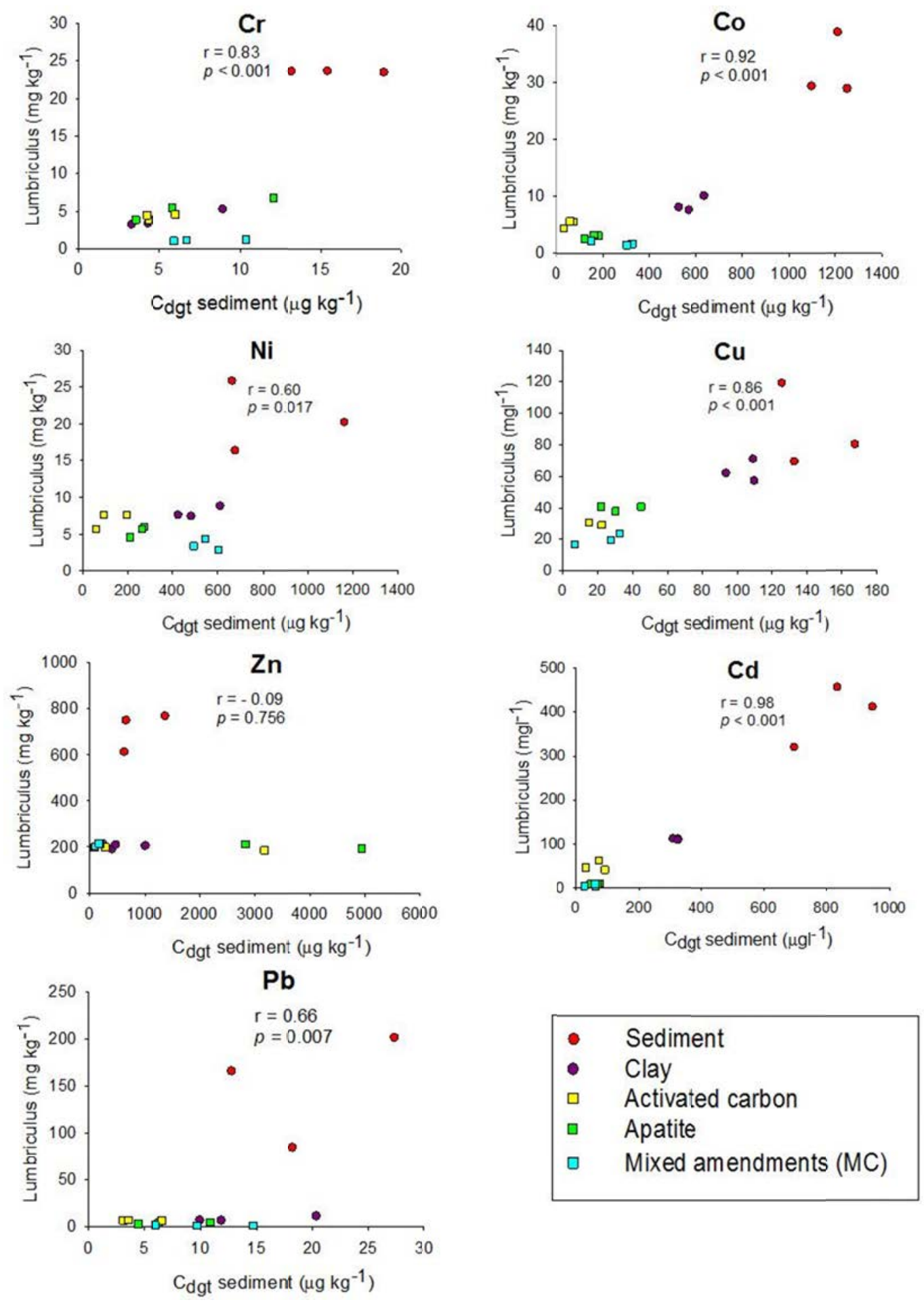

2 Figure 9. Pearson correlations between metal concentrations in Lumbriculus variegatus (whole

3 body, 10 day exposure) and metal concentrations in sediment measured by sediment DGT

4 probes. 


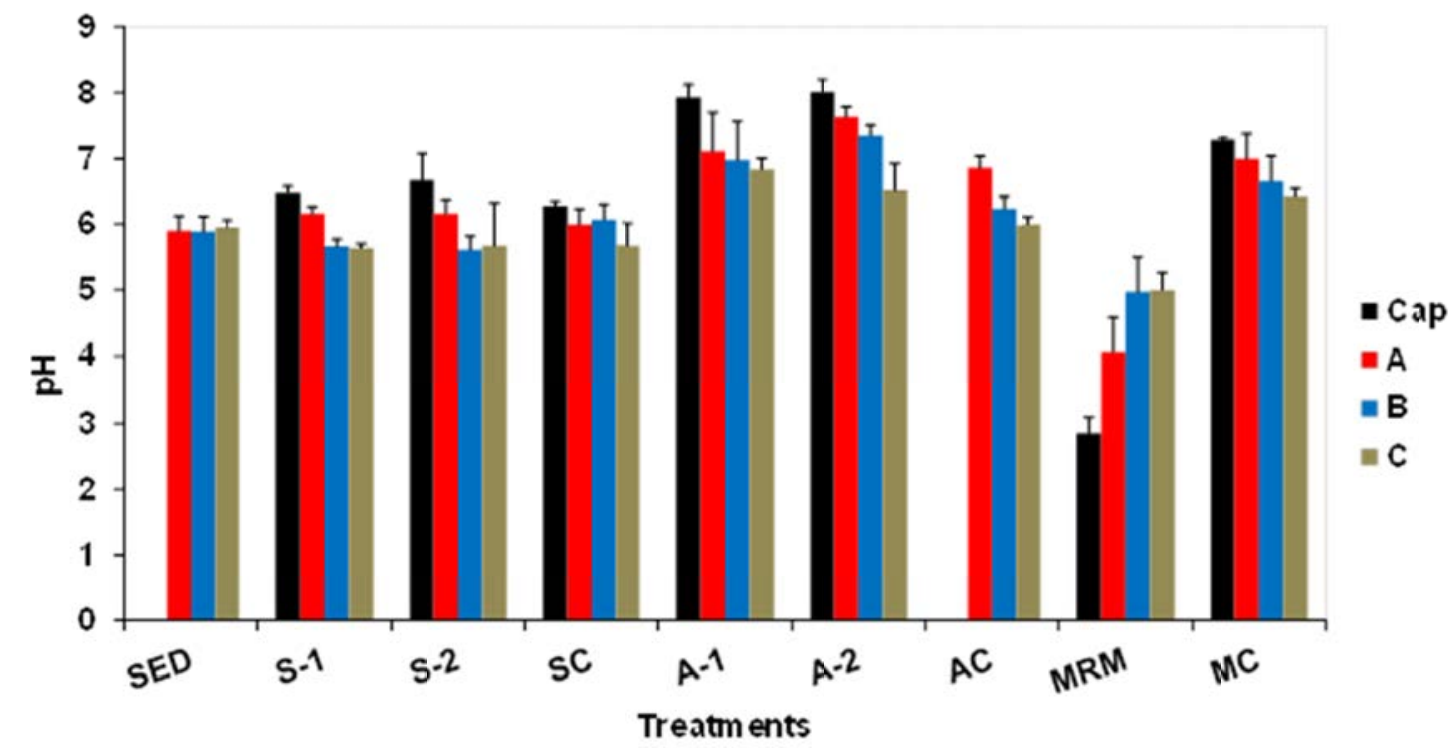

2 Figure 10. Average $\mathrm{pH}$ values $(\mathrm{n}=3)$ in cap materials and individual layers of sediment (layer A:

$30-2.5 \mathrm{~cm}$, layer B: $2.5-5.0 \mathrm{~cm}$, and layer C: $5-7.5 \mathrm{~cm}$ ) at 2520 hours; uncapped sediment

4 (SED), sediment with passive sand caps (S-1: $2.5 \mathrm{~cm}, \mathrm{~S}-2: 5 \mathrm{~cm})$, and sediment with several

5 types of active caps (SC: $2.5 \mathrm{~cm}$ silty clay, A-1: $2.5 \mathrm{~cm}$ apatite, A-2: $5.0 \mathrm{~cm}$ apatite, AC:

6 activated carbon treatment, MRM: $2.5 \mathrm{~cm}$ organoclay, and MC: $2.5 \mathrm{~cm}$ mixture of active 7 amendments).

\section{Conclusions}

We hypothesized that some sequestering agents in active caps will bind metals from

12 ongoing sources thereby reducing their bioavailability and protecting underlying remediated

13 sediments from recontamination. In contrast, metals from ongoing sources will contaminate

14 passive caps and uncapped sediment. Our results support this hypothesis:

1. The concentrations of most metals in the surface waters of mesocosms with apatite caps, mixed amendment caps, and activated carbon treatments were significantly lower than in mesocosms with passive caps (sand) and uncapped sediment. 
1 2. Survival was significantly higher for Lumbriculus variegatus in mesoscosms with active caps

2 than in mesocosms with passive caps or uncapped sediment, and whole-body concentrations

3 of most metals were lower in Lumbriculus variegatus in mesoscosms with active caps.

4 3. Organoclay MRM was not effective at removing metals from surface waters with the

5 exception of As and Se. However, toxicity and biouptake were lower in this treatment than

6 in the uncapped sediment or sand cap treatments very likely due to increased water hardness

7 associated with MRM.

8 4. Sediment DGT probes showed that ongoing contamination increased the bioavailable pool of

9 metals in the top layer of uncapped sediment but not in sediment capped or treated with 10 active amendments.

11 The remediation of contaminated sediments is a very expensive process that can be 12 negated by the continued influx of contaminants from uncontrolled sources. However, our 13 results indicate that some types of active amendments have the potential to protect remediated 14 sediments by reducing the bioavailable pool of metals emanating from ongoing sources of 15 contamination. Future work will extend these findings by quantifying how metal speciation and 16 bioavailability change in incoming contaminated sediment that is deposited over active and 17 passive caps and how these key variables are affected by bioturbating organisms. 


\section{Acknowledgment}

This work was sponsored by the DoD Strategic Environmental Research and

Development Program (SERDP) under project ER 2427. The SRNL is operated by Savannah

River Nuclear Solutions, LLC for the U.S. Department of Energy under Contract DE-AC09798861048.

\section{References}

Admiral, D. M., Garcia, M. H., Rodriguez, J. F., 2000. Entrainment response of bed sediment to time varying flows. Water Resour. Res. 36(1), 335-348.

Adriano, D. C., 2000. Trace Elements in Terrestrial Environments: Biogeochemistry, Bioavailability, and Risks of Metals, (2nd Ed.), Springer, New York, NY.

Beachler, M. M., Hill, D. F., 2003. Stirring up trouble? Resuspension of bottom sediments by recreational watercraft. Lake and Reserv. Manage. 19(1), 15-25.

Campbell, P.G.C., 1995. Interactions between trace metals and aquatic organisms: A critique of the free-ion activity model. In: Tessier, A. and D.R. Turner, eds. Metal Speciation and Bioavailability in Aquatic Systems. Wiley, Chichester, UK. 45-102.

CETCO Remediation Technologies. 2012. Company Website. www.cetco.com.

Chlopecka, A., Adriano, D.C., 1996. Mimicked in-situ stabilization of metals in a cropped soil: bioavailability and chemical form of zinc. Environ. Sci. Technol. 30, 3294-3303.

Davison, W., Zhang, H., 1994. In-situ speciation measurements of trace components in natural waters using thin-film gels. Nature, 367, 546-548.

Dixon, K. L., Knox, A. S., 2012. Sequestration of metals in active cap materials: A laboratory 
and numerical evaluation. Remediation, 22(2), 81-91.

Dragun, J., 1998. The Soil Chemistry of Hazardous Materials, (2nd Ed.), Amherst Scientific Publishers: Amherst, Massachusetts.

Fan, W., Wang, W-X., 2001. Sediment geochemical controls on Cd, Cr, and Zn assimilation by the clam Ruditapes philippinarum. Environ Toxicol. Chem. 20, 2309-2317.

Ghosh, U., Luthy, R.G., Cornelissen, G., Werner, D., Menzie, C.A., 2011. In-situ sorbent amendments: A new direction in contaminated sediment management. Environ. Sci. Technol. 45, 1163-1168.

Hach, 2013. Digital titerator, model 16900; Hach Company: Loveland, CO.

Interstate Technology and Regulatory Council (ITRC), 2014. Contaminated Sediments Remediation. Guidance Document. Washington, DC.

Knox, A. S., Kaplan, D. I., Adriano, A. C., Hinton, T. G., Wilson, M. D., 2003. Apatite and phillipsite as as sequestering agents for metals and radionuclides. J. Environ. Qual. 32: 515-525.

Knox, A. S., Paller, M. H., Dixon, K. L., 2014. Evaluation of active cap materials for metal retention in sediments, Remediation, 24(3), 49-69.

Knox, A. S., Paller, M. H., Reible, D. D., Ma, X., Petrisor, I. G., 2008. Sequestering agents for active caps - remediation of metals and organics. Soil Sediment Contam. 17 (5), 516532.

Knox, A. S., Paller, M. H., Roberts, J., 2012. Active capping technology - new approaches for in situ remediation of contaminated sediments. Remediation, 22(2), 93-117.

Kwon, S, Thomas, J., Reed, B. E., Levine, L., Magar, V. S., Farrar, D., Bridges, T. S., Ghosh, U., 2010. Evaluation of sorbent amendments for in situ remediation of metal-contaminated 
sediments. Environ. Toxicol. Chem. 29 (9), 1883-1892.

McBride, M. B., 1994. Environmental Chemistry of Soils, Oxford University Press, Oxford, U.K.

Ma, Q.Y., Logan, T.J., Traina, S.J., 1995. Lead immobilization from aqueous solutions and contaminated soils using phosphate rocks. Environ. Sci. Technol. 29, 1118-1126.

McGeer, J.C., Szebedinszky, C., McDonald, D.G., Wood, C.M., 2002. The role of DOC in moderating the bioavailability and toxicity of copper to rainbow trout during chronic waterborne exposure. Comp Biochem Physiol. 133C, 147-160.

The National Research Council (NRC), 2001. A Risk Management Strategy for PCBContaminated Sediments, National Academies Press, Washington, DC.

The National Research Council (NRC), 2003. Bioavailability of Contaminants in Soils and Sediments, National Academies Press: Washington, DC.

Paller, M. H., Knox, A. S., 2010. Amendments for the remediation of contaminated sediments: Evaluation of potential environmental impacts. Sci. Total Environ. 408, 48944900.

Palermo, M., Maynord, S., Miller, J., Reible, D., 1998. Guidance for in-situ subaqueous capping of contaminated sediments. U.S. Environmental Protection Agency, Great Lakes National

Program Office, Washington, DC (EPA 905-B96-004).

Piol, M., Lopez, A., Mino, L., Afonso, M., Guerrero, N., 2006. The impact of particle-bound cadmium on bioavailability and bioaccumulation: A pragmatic approach. Environ. Sci. Technol. 40, 66341-6347.

Strategic Environmental Research and Development Program and Environmental 
Security Technology Certification Program (SERDP\&ESTCP), 2012. Summary

Report: SERDP and ESTCP Workshop on Research and Development Needs for LongTerm Management of Contaminated Sediments. SERDP\&ESTCP, Alexandria, VA, Accessed October 16, 2012, at https://www.serdp-estcp.org/Program$\underline{\text { Areas/Environmental-Restoration/Contaminated-Sediments. }}$

Shi, T., Jia, S., Chen, Y., Wen, Y., Du, C., Guo, H., Wang, Z., 2009. Adsorption of Pb (II), Cr (III), Cu (II), Cd (II) and Ni (II) onto a vanadium mine tailing from aqueous solution. J. Hazard. Mater. 169, 838-846.

Singh, S. P., Tack, F. M., Verloo, M. G., 1998. Heavy metals fractionation and extractability in dredged sediment derived surface soils. Water Air Soil Pollut. 102, 313-328.

U.S. Environmental Protection Agency (U.S. EPA), 2005. Contaminated Sediment Remediation Guidance for Hazardous Waste Sites. U.S. Environmental Protection Agency, Office of Solid Waste and Emergency Response, Washington, DC (EPA-540-R-05-012).

U.S. Environmental Protection Agency (U.S. EPA), 2007. Inductively coupled plasma-mass spectrometry, Test Methods for Evaluating Solid Waste, Physical/Chemical Methods (SW-846). U.S. Environmental Protection Agency, Office of Solid Waste, Washington, DC (EPA-846-R-2007-001).

U.S. Environmental Protection Agency, 2016. National Recommended Water Quality Criteria. U.S. Environmental Protection Agency, Office of Water. 2016. Accessed March 17, 2016, at https://www.epa.gov/wqc/national-recommended-water-quality-criteriaaquatic-life- criteria-table.

22 Wright, J. V., Peurrung, L. M., Moody, T. E., Conca, J. L., Chen, X., Didzerekis, P. P., 


\section{1}

12

Wyse, E., 1995. In-situ Immobilization of Heavy Metals: Apatite Mineral Formations, Technical Report submitted to the Strategic Environmental Research and Development Program, U.S. Department of Defense; Pacific Northwest National Laboratory, Richland, WA.

Zhang, H., Davison, W., 1995. Performance-characteristics of diffusion gradients in thinfilms for the in-situ measurement of trace-metals in aqueous-solution. Anal. Chem. 67, 3391-3400.

Zhang, H., Zhao, F. J., Sun, B., Davison, W., McGrath, S. P., 2001. A new method to measure effective soil solution concentrations predicts copper availability to plants. Environ. Sci. Technol. 35, 2602-2607. 